\title{
Effect of Heat Treatment in A Fermented Milk Product Naturally Bio-Encriched in Folate Using Lactic Acid Bacteria
}

\author{
Jonathan Laiño (I), Marianela Juarez del Valle (I), Graciela Savoy de \\ Giori (I), Jean Guy LeBlanc (I) \\ (I) CERELA-CONICET - Centro de Referencia para Lactobacilos (Chacabuco 145, San Miguel \\ de Tucuman, ARGENTINA)
}

\section{Resumo}

Heat treatment is a key step in food processing to ensure the microbiological food safety before human consumption. Even though folates are present in a wide range of foods, conventional yogurts are not considered a good source of folates. Many species of lactic acid bacteria, including some starter cultures, can produce folates; however the use of novel folate producing strains could be limited since their effects on humans have not been evaluated. Heat-killing them is an option but no information is available on the effect of this treatment on folate concentrations. The aims of this study were to evaluate: a) the capacity of the strain Lactobacillus (L.) amylovorus CRL887 to grow in a folate-free culture medium and to produce this vitamin; b) its capacity to produce folate in milk when grown as a co-culture with other folate producing strains, c) the effect of heat treatment on folate levels in the folate bioenriched yogurt, and d) the stability of folate levels on heat treated fermented milk during storage. L. amylovorus CRL887, was able to grow in a folate-free culture medium (reaching $8.1 \times 10 \mathrm{e} 8 \mathrm{CFU} / \mathrm{mL}$ ) and produced high concentrations of the vitamin $(76.3 \pm 1.8 \mu \mathrm{g} / \mathrm{L})$. This vitamin production was dependent of growth. This strain was then combined with folate producing starter cultures L. delbrueckii subsp. bulgaricus CRL871, CRL872, and Streptococcus (S.) thermophilus CRL803 and CRL415 to elaborate different yogurts. One combination

\footnotetext{
Referência:

Jonathan Laiño, Marianela Juarez del Valle, Graciela Savoy de Giori, Jean Guy LeBlanc. Effect of Heat Treatment in A Fermented Milk Product Naturally Bio-Encriched in Folate Using Lactic Acid Bacteria. In: Anais do 12 Congresso Latinoamericano de Microbiologia e Higiene de Alimentos - MICROAL 2014 [= Blucher Food Science Proceedings, num.1, vol.1]. São Paulo: Editora Blucher, 2014. DOI 10.5151/foodsci-microal-218
} 
produced a yogurt with the highest folate concentration $(263.1 \pm 2.4 \mu \mathrm{g} / \mathrm{L})$, one portion of which could provide $14 \%$ of the Recommended Dietary Allowance. Heat treatment was applied to eliminate L. amylovorus CRL887 since this strain was never used for the production of fermented foods for human consumption. This treatment was applied on this bioenriched yogurt and was effective in eliminating all viable bacteria without affecting the folate concentrations. Also folate levels were stable during 28 days of storage at $4{ }^{\circ} \mathrm{C}$. This is the first report that described the capacity of a strain of L. amylovorus to grow and produce folate in a folate-free culture medium. This strain was successfully used to elaborate a bio-enriched in folate, and heat treatment process did not decrease the folate levels even after 28 days of storage at $4{ }^{\circ} \mathrm{C}$.

Palavras-Chave: FOLATE, HEAT TREATMENT, LACTIC ACID BACTERIA, FOOD SAFETY

\section{Agência de Fomento:}

